\title{
A Reflection on the Impact of Christian and Muslim Prayers on Moral Behaviour in the Ghanaian Society
}

\author{
Ron Macaulay ${ }^{1}$ \\ ${ }^{1}$ Global Theological Seminary, Accra, Ghana.
}

\begin{abstract}
This article reflects on the impact of Christian and Muslim prayers on societal moral attitudes. It also analyses the belief, needs, modes, advantages and problems of prayer amongst the two religions. The discussions reveal that the two religions acknowledge the importance of prayer. They also share similar views on the subject; however, with regard to some elements of prayer, they share divergent views. Some notable challenges in religious pluralism in Ghana are discrimination and superiority as a result of doctrinal differences. The study recommends that, since Ghanaians have become "notoriously religious," their prayers should reflect and result in moral lives that depict the ethical teachings of their religions. This is because the exhibition of moral values is a sine qua non for having a positive impact on society. Furthermore, the fact that contemporary education serves students from a variety of religious backgrounds, can pose many challenges to educators. Hence educators and policy makers need to provide guidelines and strategies for teaching students to understand, accept, and value religious pluralism. Those policies need to be discussed by students and their families that do not only accept and support religious pluralism, but diversity in unity. This paper contributes to current discussions on religious intolerance.
\end{abstract}

\section{Correspondence: Ron Macaulay Email: ronmacaulay12@gmail. com}

Publication History Received 19th May, 2021, Accepted 18th June, 2021, Published online 28th June, 2021.

Keywords: Pluralism, intolerance, prayer, morality.

\section{INTRODUCTION}

It is believed that teaching and prayer as religious duties go hand-in-hand. Therefore, prayer offered to God should depend on his Word, which can guide people's ethical conduct. For that reason, Ghanaians expect that Christians and Muslims would teach and pray to inculcate a sense of morality that should result in shaping societal attitudes. Despite the fact that many have this high expectation, it has been observed that the role religion plays in shaping the moral life of many, however, is fading away. Examples of immoral behaviour are gross corruption, armed robbery, kidnapping, "sakawa (internet fraud)", sexual immorality among others.

This topic, of course, is very ample and complex, and so this study only provides an introductory reflection. Indisputably, Ghanaians are very religious, and religion occupies a very indispensable place in their lives. Though there are three dominant religions in Ghana, which are Christianity, Islam and African Indigenous/Traditional Religion, the overarching purpose of this study seeks to unravel the impact of prayer as a religious duty embedded in Christianity and Islam.

Irene Osemeka postulates that religious diversity and pluralism are used interchangeably to describe the wide range of religious faiths that exists. ${ }^{1}$ She notes that religious diversity points out the differences in religious faiths whereas religious pluralism is "synonymous with freedom of worship and expression" but its main focus is on the idea of, "live and let us live." ${ }^{2}$ Also, in an attempt to describe what religious pluralism means, Goran Collste asserts that

\footnotetext{
Irene N. Osemeka, "The Management of Religious Diversity in West Africa: The Exceptionalism of the Wolof And Yoruba In the Post-Independence Period," Historia Actual Online, No. 33 (2014): 62.

2 Osemeka, "The Management of Religious Diversity in West Africa," 62.
} 
"religious pluralism denotes an environment of the existence of more than one religion."

Nevertheless, religious pluralism does not easily accept multiple paths, and one of these paths is prayer. Prayer is offered to God or a deity about his own moral nature, such as his holiness, love, mercy, forgiveness; also about oneself, circumstances, and people in the world. It is believed that prayer as a religious duty to God needs to influence people's moral life. According to Ron Macaulay, one important dimension of religion is morals. ${ }^{4} \mathrm{He}$ argues that morals in the indigenous Ghanaian perspective deal with the question of what is right and wrong, good and evil, which has to do with the impact of prayer on people's conduct in society. ${ }^{5}$

The limited scope of this study sheds light on its conceivable issues. The study also seeks to analyse the belief in prayer, the need for prayer, the modes of prayer, advantages and the problems of prayer. This is not to pronounce judgement on any of the religions that are under study but to take a serious reflection on the undeniable reality of religious pluralism, and to acknowledge the diversity existing in indigenous Ghanaian society.

It has been asserted that religious diversity believes that one religious perspective is superior to the perspectives of others. ${ }^{6}$ This will lead to the assertion of whether there are divergent views and similarities in the belief systems and practices of the two religions. Despite divergent views, Ghanaians hope for religious diversity in unity.

\section{The Belief of Prayer in Christianity and Islam}

Indeed, it is prudent to ask whether there are values within the religious prayers offered by both Christians and Muslims. Prayer is, indeed, one of the religious practices that is visibly patronised by a lot of such religious groups. Simon Blackburn defines prayer as any kind of communication believed to be addressed to a deity. ${ }^{7}$ It is one of the aspects of spirituality, and there exist significant differences of opinion among individuals of different religious beliefs. Such diversity of opinion though is nowhere more evident than in the area of religious thought is predominant among Christians and Muslims. Even though they have diverse views and belief systems, they have certain things in common, such as bowing, prostration, and standing in prayer.

These religions have the challenge of tempting to compete with each other when it comes to doctrinal issues relating to prayer, as to who prayer should be directed to. While Christians believe that prayer should be directed to God through Jesus Christ, Muslims hold the view that there should not be any mediator or intermediary between Allah and the petitioner. However, the two religions understand that it is in the area of prayer that God works in human lives.

Both Christians and Muslims believe that man is created in the image of God or Allah. This similarity can be found in Genesis 1:26-27 and Surah 2:30. Male and female are both created in the image of God, which connotes and also contributes to a sense of fellowship between God or Allah and man/woman. Fellowship which has to do with prayer as a means of communication with God is accessible for both man and woman to speak and relate with his or her creator God or Allah. This has become an essential part of God's nature in Christianity and Islam, which can be inferred that God communicates with or speaks to people.

Both religions believe that prayer could either be offered to God personally, or on behalf of someone. This means that when the person requests that prayers be offered for a particular reason, then it is logical to conclude that God also works in the area of the prayer request. It is, for this reason, the subject of prayer helps one to understand how God works in the lives of both Christians and Muslims.

The writer is in total agreement with Cynthia Doms who postulates that many of those who depend on prayer and a relationship with God also depend on God's Word as a guideline for their behaviours. This sets up the expectations on how to behave, creating a sense of structure and a vision of moral health for those who rely on a prayer life with a loving God. ${ }^{8}$

\section{The Importance of Prayer in Christianity}

God's ability and a means to communicate with his creation calls for prayer, hence prayer means communication with God, as stated earlier. God likes prayer because he relates with people as they pray. Without prayer, he would cease to be a living God, but a speechless idol. Hence, in the Christian Bible, the Lord Jesus taught his disciples to pray "Our Father in heaven ..., give us this day our daily bread and forgive us our trespasses...." (Matt. 6:9-13). Also, "Call to me and I will answer you...." (Jer. 33:3). Again, "If My people who are called by My name will humble themselves, and pray and seek My face, and turn from their wicked ways, then I will hear from heaven, and will forgive their sin and

\footnotetext{
Ed Goran Collste, Religious and Ethnic Pluralism in Malaysia (Linkoping: University Electronic Press, 2006 ), 10.

4 Ron Macaulay, “The Future of Taboos in Indigenous Ghanaian Morality” E-journal of Religious and Theological Studies, 6 no. 7 (2020): 334. https://doi.org/10.38159/erats.2020101

Macaulay, "The Future of Taboos in Indigenous Ghanaian Morality,” 334.

Philip Quinn, Religious Diversity and Religious Toleration, International Journal for the Philosophy of Religion, (2001), 57-80.

Simon Blackburn, Oxford Dictionary of Philosophy (New York: Oxford University Press, 2005), 288.

Cynthia B. Doms, "The Positive Effects of Prayer and Faith: The Positive Effects of Prayer and Faith on Mental Health With an Overview of Integrating the

Fifth Task of Life" (Master of Arts in Adlerian Counseling and Psychology, June 2011), 32.
} 
heal their land" (2 Chron. 7:14). Furthermore, "If you ask anything in My name, I will do it" (John 14:14). These show how "terribly" important prayer is to God. The very fact that Jesus asked Christians to pray is clearly evident that God is interested in them, and also answers their prayers. They believe that their prayers are answered when they follow Jesus' instructions. Dickson established that by this, Christians therefore, develop a sincere life of prayer to God that is based upon a belief that God truly works in their lives. ${ }^{9}$

Christians believe that since prayer is the medium by which one can communicate with God, it should be offered to him anywhere and at any time as often as one wishes, as instructed to, "Pray without ceasing" (1Thes. 5:17). To the Christian, prayer is offered in many forms, some of which are:

1. Prayer is offered through praises where melody is made to God in form of songs and the use of musical instruments (Ps. 150; Eph. 5:19).

2. Adoration is where adoring words are said to God in order to exalt or extol him (Ps. 68:4).

3. Confession of $\sin$ is made to show a deep sense of remorse for the sins committed (Ps. 51; 1John 1:9).

4. Speaking God's word back to him as a prophetic prayer concerning bad situations (Eze. 37:4-7).

5. Intercession is where requests are made on behalf of others (1Tim. 2:1-4).

6. A petition is telling God about one's needs (Phil. 4:6).

7. Fasting and prayer as one of the most important forms of prayer is refusing to eat, especially, taking solid food (2 Chron. 7:14; Dan. 10:2-3; Matt. 17:21) in order to remain focused on God. The Christian observes varieties of fasting and prayer periods, such as one day, three days, seven days, twenty-one days, forty days and beyond and these periods are often accompanied by the organisation of deliverance services in many churches.

Notwithstanding these forms of prayer, the Christian believes that one's focus on the Word of God as he prays does not displace the work of the Holy Spirit in his life. In addition, prayer is done either on an individual basis, on a pastor and a member basis, or on a pastor and congregational basis. Christians believe that as one prays, God responds. Also, participating in prayer may affect the way that individuals handle anxieties and stress in their lives. Apostle Paul said, "Do not be anxious about anything, but in everything by prayer...and the peace of God...will guide your hearts and minds" (Phil. 4:6-7).

\section{The Importance of Prayer in Islam}

Muslims are very particular about their five daily prayer times called "salat" as taught by the prophet Mohammad. They are devoted and committed to it, regardless of where they find themselves. Whether they are alone or in the company of others; they are ready to pray provided they have little water to perform the ablution also called "wudu." - washing of the head, hands and feet. Before praying, Muslims must be clear of mind and of body. Muslims pray at mosques, where they can share their faith with others. But any quiet place, even a corner of an office or home, can be used for prayer. ${ }^{10}$ To pray, Muslims face the direction of Mecca. When they are ready, they usually lay a special prayer mat before they say their set of prayers in Arabic. A different position is taken for each part of the prayer. ${ }^{11}$ The various postures are standing, bowing, and prostration.

Muslims believe in prayer as indicated in Surah Al-Isra 17:78-79 which says, "Establish regular prayer - as the sun decline till the darkness of the night, and the recital of the Qur'an at dawn, for the recital of the Qur'an at dawn is witnessed. And rise from sleep during the night as well...." For this reason, it is obligatory to perform five times daily prayers at specific prescribed time ranges (Surah Taaha, Ayat 130). Therefore, to the Muslim,

1. The first prayer time which is known as Fajr ranges from around 4 a.m. to 5 a.m. This prayer starts off the day with the remembrance of God.

2. The second period known as Dhuhur ranges from about 12.30 p.m. to 1.30 p.m. Thus, after the day's work has begun, one breaks shortly after noon to again remember God and seek his guidance.

3. 'Asr as the third period ranges from 3 p.m. to 3.30 p.m. Muslims take a few minutes to remember God and the greater meaning of their lives.

4. The fourth which is known as Maghrib ranges from about 6 p.m. to 6.30 p.m. Muslims remember God again as the day begins to come to a close. Finally,

5. The last period named 'Isha ranges from 7. p.m. to 8 p.m. Before retiring for the night, Muslims again take the time to remember God's presence, guidance, mercy, and forgiveness. ${ }^{12}$

\footnotetext{
9 Roger E. Dickson, Biblical Research Library: The Work of God in Response to Prayer (South Africa. Cape Town: 2008), 93-94.

10 Huda, "The 5 Muslim Daily Prayer Times and What They Mean." Feb 08, 2021. Accessed on April 15, 2021.

https://www.learnreligions.com/islamic-prayer-timings-2003811

11 David Self, The Lion Encyclopedia of World Religions (Oxford: Wilkinson House, Jordan Hill Road, 2008), 44-55.

12 Excerpts of an interview conducted by the author with Ali Baba Muhammed, an MPhil in Study of Religions student of the University of Ghana, Legon. The interview was held on 15th April, 2014.
} 
These and other forms of prayer are observed by Muslims. The Muslims also observe fasting and prayer as one of the most important aspects of praying to Allah. According to the Islamic religion, they fast for 30 days, which is broken every evening. It is a period that is observed in the month of Ramadan (September), which is known as "Sawm."13 However, according to John Mbiti, Nupe Muslims do not follow strict Islamic traditions. For example, they observe only two of the five pillars of Islam, which are daily prayer and fasting. ${ }^{14}$

\section{The Need for Prayer}

Taking cognisance of the preceding accounts, it is pertinent to consider that prayer occupies a very essential place in both religions. Elom Dovlo observes that although there are modern medical facilities in the form of hospitals and clinics in Ghana, there is much recourse to religion for the purpose of the sustenance and restoration of good health. ${ }^{15}$ There is a general belief that there are spiritual connotations to the various physical and psychological problems people face, which compel them to seek medical and psychological solutions.

Many are those who are spiritually tormented and incapacitated by diverse kinds of ailments. In this case, attention is not paid exclusively to the physiological aspect but to the spiritual causes as well, for good health and well-being can only be attained when both body and spirit are taken care of. ${ }^{16}$ In such cases, using only physical means to solve spiritual issues is often not feasible. Hence, some may call for both to go side-by-side: spiritual and medical solutions.

A large number of Ghanaian churches, in the quest to handle prayer effectively, adopt different approaches. Some of the approaches are the use of prayer warrior groups, deliverance ministry, and corporate or congregational prayer sessions which are led by Ministers/Pastors to deal with those problems. These groups are identical with both Mainline and Pentecostal/Charismatic churches. They pray for the people present, and those who are absent alike.

In Islam, there are no identifiable prayer groups, such as "Prayer warriors and deliverance teams" as is the case in Christianity. However, there is a similarity in certain aspects of who administers prayer. Prayer is offered by Imams or leaders for their members on a one-on-one basis as done by Pastors for their members in the Christian church. However, group "deliverance" ministration (exorcism) is not observed in Islam in the manner in which it is conducted in Christianity through the laying on of hands on the people being prayed for. Nevertheless, both religions believe in fasting and prayer and singing to God or Allah as a form of prayer.

\section{Advantages of Public Prayer in Ghana}

Public prayer has been very advantageous in national issues, such as the prayers offered before, during and after presidential and parliamentary elections in Ghana. Others are said on the occasion of Ghana's celebration of Independence, the inauguration of the presidents-elect, and other public functions. At these state functions, each of the religious group leaders is called upon to offer prayer as a means of fostering unity and peace among religious groups.

Also, there have been considerable instances where the Christian Council of Ghana, Ghana Pentecostal and Charismatic Council, and other Christian organisations organise fasting and prayer programmes for their members to pray for the protection, peace and tranquillity of the country. These prayer meetings sometimes attract some politicians who participate to show their keen interest in it. One instance where such prayers were offered was during the devastating COVID-19 period. During this period mass prayers were held across the whole country to seek God's protection.

One identifiable Christian prayer group is the Aglow International, formally Women's Aglow Ministry, a vibrant prayer "ministry" which comprises mostly women from all the sixteen regions of Ghana. This group usually meets monthly at The Independence Square to offer intercessory prayers to God on behalf of the country. These women pray for protection, prosperity, unity, peace and tranquillity to prevail in the country. They courageously pray with the belief that their prayers would be heard and answered. Surprisingly, though this ministry is identifiable as a women's group, it currently attracts men who join them to pray, and also play musical instruments during prayer sessions.

Muslims also play their roles praying for the peace of the country on Fridays. Muslims use the celebration of the festivals of Id-ul-Fitr and Id-ul-Adha ${ }^{17}$ to intercede on behalf of the country. For the fact that Ghanaians are religious, these prayer meetings often attract ministers of state and other prominent persons. These prayer meetings are organised in open public places which do not call for public disturbance. This involves all gender, regardless of age and social status as an act of solidarity among the Muslim community.

However, one is yet to see both Christians and Muslims coming together to intercede on behalf of the country to show true religious pluralism and diversity in unity in Ghana. Interestingly, many people are of the view that all

\footnotetext{
Self, The Lion Encyclopedia of World Religions, 45.

John S. Mbiti, African Religions \& Philosophy (New Hampshre: Heinemann Educational Books Inc., 1989 ), 239 - 240.

Elom Dovlo, "Healing and Religious Pluralism in Ghana" (Draft Paper Presented at Graduate Seminar, University of Stockholm, September, 2006 ), 1.

Asare Kofi Opoku, West African Traditional Religion (Accra: FEP International Private Limited, 1978 ), 91.

Self, The Lion Encyclopedia of World Religions, 48.
} 
religions are the same, but are they? Mbiti concludes that it is religious laziness which drives people to this concept of sameness. ${ }^{18}$ This means that it would be very difficult for the two religions to hold a prayer meeting just like it is done during the national intercession prayer organised by Aglow International. Perhaps, there must have been a gap which may have been serving as grounds for the difference. Nevertheless, Aglow International needs to be encouraged to grow.

\section{The Problems of Prayer in Christianity and Islam}

Can prayer pose problems to those who offer it? Of course, the mode of prayer can be problematic sometimes, particularly when prayer "disturbs" others who are not part of the praying group. The phenomenon of loud prayer is one of the easily identifiable problems which has become common among Christians and Muslims in Ghana. Though Christians believe in both silent and loud prayers, they sometimes make excessive noise when sophisticated musical instruments are employed even where only a handful of people meet.

Donald Bloesch posits that there are occasions where prayer is said or offered to God in silence. God listens to prayers even when they are not voiced out loudly. ${ }^{19}$ This is evident when he answered Hannah's silent prayer when she prayed for a child (1Sam. 1:13-15). Conversely, he also answered loud prayer as it was in the case of David in Psalm 17:1, and of Stephen who fell on his knees and cried out, "Lord, do not hold this sin against them..." (Acts 7:60). The results may be the same, but the modes or methods differ.

Loud Christian prayers are identifiable with the Pentecostal renewal movements, a term that encompasses Pentecostal groups that "consciously seek to experience and affirm the active presence of the Holy Spirit as part of normal Christian expression." Some of the prayer sessions are characterised by speaking in tongues, prophesying, visions, healing and miracles among others. ${ }^{20}$

Also, during congregational prayer sessions, musical instruments are used and loud noise is made, both in song ministrations and prayer times. In the course of this, they tend to disturb public peace, which many a time generates into heated arguments and conflict between churches and communities.

Muslims also have their share of noise-making when they begin to use public address systems during their prayer times to call to worship. In Muslim communities, people are reminded of the salat by the daily calls to prayer, known as adhan. The adhan is delivered from mosques by a muezzin, the mosque's designated caller of prayer. During the call to prayer, the muezzin recites the Takbir and the Kalimah. ${ }^{21}$ According to Osman Bari, the qualification to lead prayers in the Islamic religion is the ability to acquire the relevant knowledge that would link the leader with Allah. Also, such leaders should be men of wisdom who are knowledgeable in the Qur'an and the revealed scripture of other religions. ${ }^{22}$

The public address system is also used by Imams when leading prayer sessions. The question that comes to the fore is: why most church denominations and Muslims pray loudly as though God or Allah were deaf? Notwithstanding the vital role prayer plays, one cannot overlook the moral implications of loud prayers.

The public often feels embarrassed and offended when both Christians and Muslims are engaged in noisemaking activities, while at the same time seeking national unity. This situation sometimes generates into a conflict between churches and traditionalists. Most of the time, musical instruments are seized at various places when the ban is placed on drumming and noise-making. A typical example is the period of the Ga Homowo festival. Charismatic churches feel that the ban on drumming and noise-making infringes on their rights to freedom of worship. This situation eventually leads to conflict which is not dying down. But can freedom be kept under control as one goes about how to make moral choices? This is because many people can make noise under the pretence of their rights to freedom.

To this effect, The Environmental Protection Agency (EPA) as a governmental organisation has been put in place to check noise-making, regardless of the venue. This is an institution who among its functions issues notices in the form of directives, procedures, or warnings to any other person or body for the purpose of controlling the volume, intensity and quality of noise in the environment. ${ }^{23}$

One would recommend that to live and operate in a peaceful atmosphere and to provide a safe environment, loud noise needs to be controlled to suit the hearing of everyone. This will also help children and adults not to develop hearing problems.

\footnotetext{
18 Mbiti, African Religions \& Philosophy, 258.

19 Donald G. Bloesch, The Struggle of Prayer (San Francisco: Harper \& Row Publishers, 1980), 158.

20 Johnson K. Asamoah-Gyedu, African Charismatic: Current Developments within Independent Indigenous Pentecostalism in Ghana, (Leiden: African Christian Press, 2005), 16.

21 Huda, "The 5 Muslim Daily Prayer Times and What They Mean."

22 Osman B. Bari, A Comprehensive History of Muslim and Religion in Ghana (Dezine Focus Thinking \& Publishing Co., 2009), 9-10.

23 The Environmental Protection Agency Ghana. Act, 1994 (ACT 490). Accessed on 15 April, 2021.

http://www.epa.gov.gh/epa/sites/default/files/downloads/environmental\%20protection\%20agency\%20act $\% 201994$.pdf
} 
Interestingly, as both Christians and Muslims pray, competitive tendencies also prevail. While Christians engage in an aspect of prayer as a means of inviting God's power to win souls, they would like to win other Christians to their churches instead of converting unbelievers to Christ; some Muslims also think in similar terms. ${ }^{24}$ This behaviour goes against the Lord's expectation "that they all may be one" (John 17:21). The question posed by John Dickson is whether it is possible that the one God that both religions claim to worship is the same God worshipped in different ways in churches and mosques? $?^{25}$ This is an ongoing debate.

Furthermore, many are those who seek "quick" answers through prayer from all angles where "holy water," "anointing oil," "stickers," and "candles" are sold, especially, in the Christian church and also by Mallams. Sometimes photographs, money and other items are demanded from prayer seekers. However, to Bloesch, the reason why some prayers are not answered by God is due to one having enmity with God and one's neighbour. ${ }^{26}$ This is because God considers the attitude of the heart that is offering the prayer, and not those items.

One notable characteristic is that the church started on a very good note where God's Spirit was always available to meet people's needs. For instance, during the epoch of the early church, "...they brought the sick out into the streets and laid them on beds and couches that at least the shadow of Peter passing by might fall on some of them. Also, a multitude gathered from the surrounding cities to Jerusalem, bringing sick people and those who were tormented by unclean spirits, and they were all healed" (Acts 5:15-16). These and many miracles were performed by the apostles of Jesus Christ without any struggle. The question is: why is it difficult for current Christians to continue the way the early church started? Some of the reasons might be individualism, and lack of sincere love for one another. This is a paradigm shift: Christians seeking miracles instead of miracles following them (Mark 16:17-18). Hence Justin Welby, Archbishop of Canterbury, asked people to pray for three things: "That all Christians find new life in Jesus Christ... that all those you meet...might see something of Jesus..., and for the church to overflow with the reality of the presence of Jesus." ${ }^{27}$

Besides the aforementioned problems, another highly problematic area is how adherents of different religions approach prayer in some second-cycle religious educational institutions (Mission Schools). The limited scope of this study will not allow a thorough analysis of issues related to Basic and Tertiary institutions. Hence, the writer selected not by a random procedure, but intentionally and purposively picked the second-cycle institutions. This is because there has been a recent disagreement in one of these institutions about fasting at the time of this write-up; a development which is yet to be resolved. Perhaps, the overarching purpose of the respective religions to establish religious educational institutions in Ghana is to promote their faith, and also instil morality into the students. Basically, it is believed that this method will help bring sanity to Ghanaian morality. Such proprietorial power is exercised according to their schools' rules and regulations independently.

Undeniably, today's schools are serving students from a variety of religious backgrounds. This is a place where people from different places come to live together; many different ideas are discussed and are likely to tolerate change but are sometimes met with disagreements. Ghana, though known to be a peaceful country, is sometimes confronted with, intolerance, superiority, and violent conflicts that are likely to mar the nation. ${ }^{28}$ This situation has invited many questions.

Some of the rhetorical questions that come to the fore are: should Christian students be allowed to escape Islamic prayer in Islamic schools? Also, should Muslim girls be allowed to wear either "hijab" or "burqa" in Christian schools? According to Encarta Dictionary, while a hijab is a head covering worn by some Muslim women to conceal their hair and neck, a burqa is a garment with veiled eyeholes covering the entire body. Again, how does the increasing religious diversity to which students are exposed, affect public school curricula? ${ }^{29}$ Should students from various religious backgrounds be allowed to fast and pray as religious rites? These growing phenomena pose a challenge to the secondcycle institutions.

Like in some other societies in the world, the "misuse" and "misunderstanding" of religion has been a source of conflict in Ghana. Although different religious beliefs are a source of support and learning for students, they can create divisions, superiority, and many other challenges. It would be accepted that school curricula could significantly be affected due to religious pluralism and diversity in public schools if considerable importance is given to religion as against unity.

Nevertheless, the unqualified absolutist: a deontologist holds that the rule determines the result and not the reverse. An act is good because it is good, regardless of the results. ${ }^{30} \mathrm{He}$ looks at the intrinsic value of the rules.

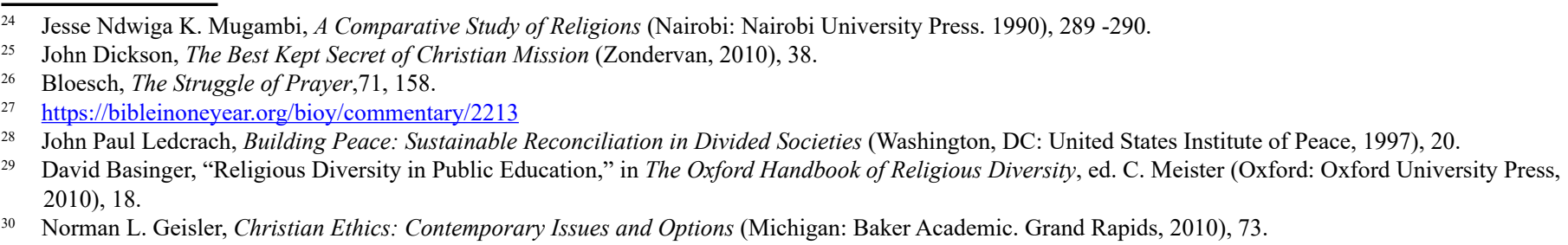


This means that since schools have their rules and regulations, they need to be obeyed to inculcate morality. To the unqualified absolutist, it is not about the number of students produced, but the quality of students produced and how they behave in society morally.

The Anamuah-Mensah Educational Reform Review Committee report in 2002 recommended the moral and religious upbringing of children with the view that it will propel them to become responsible citizens for peaceful coexistence and nation-building. ${ }^{31}$ According to Kunzman, most public school teachers agree that increasing students' understanding of diverse religious perspectives is important as this will have positive social outcomes..$^{32}$ It is often argued that, helping students better understand the increasing diversity, including religious diversity they face will better prepare them to live in a peaceful productive manner with those with differing cultural, or religious values. Hence educators and policymakers need to provide guidelines and strategies for teaching students to understand, accept, and value religious diversity. Those policies need to be discussed by students and their families to create a school environment that accepts and supports religious diversity. ${ }^{33}$ This is to enhance students' moral life both in school and society.

\section{The Moral Impact of Prayer on Ghanaian Society}

In Ghana, there exists a society of religious pluralism because the constitution of Ghana permits freedom of worship, "but subject to respect for the rights and freedoms of others and for the public interest." ${ }^{34}$ The problem arises in one's bid to exercise one's rights. Christianity, which can be considered as the larger religious group has its own pluralistic structure of faith, such as the Roman Catholic church, and the Protestant church which comprises Pentecostal, Charismatic, and Independent churches.

Some notable challenges in religious pluralism in Ghana are discrimination, and superiority as a result of doctrinal differences. Hence, religious pluralism has become a challenge to individuals, families, friends and society. According to John Hick, "each of these great religious traditions, then, assumes in one way or the other, its own unique superiority." ${ }^{35}$ Notwithstanding the differences, Macaulay argues that the Bible is clear on religious and moral matters. It enjoins all that, "You shall have no other gods before me" as a religious matter accompanies by prayer as people worship God (Ex. 20:3; 2 Kings 17:35). The moral aspects are "You shall not murder," "You shall not commit adultery," "You shall not steal," "You shall not bear false witness against your neighbour," and "You shall not covet...." (Ex. 20:13-17). ${ }^{36}$ One would draw the inference that, after the performance of the religious aspect, worship of God is incomplete if the moral aspect is neglected.

Incontrovertibly, the role religion plays in shaping the moral life of the people of Ghana, however, is fading away. This is because some scholars maintain that there is a connection between religion and morality in Ghana, therefore, actions that promote human welfare or interest are good, while those that detract from human welfare are bad. $^{37}$

One would assert that the problem is with the religious bodies, which have to do with their doctrines, which might probably be influenced by those who interpret them. In other words, this could be the result of what is termed as "religious language problem." This means that the interpretation of faith depends on the language through which the religious faith is explained. Also, the limit of one's language is the limit of one's world of interpretation, which affects the meaning of the faith. Since it is believed that the doctrine received is the doctrine believed, everyone has "notoriously" believed in his religion to be the best. This calls for careful scrutiny of the faith since they will be judged by God's mysterious standards.

Notwithstanding the difference, the doctrines of each of these religions have some belief system with promises, probably, which one would not want to lose. To juxtapose the position of Christians with that of Muslims, both believe that heaven is real, where they will one day be received up to enjoy, a place everyone is striving to be part of (1 Thes. 4:15-16; Qur'an Surah 80:21-22). But their expected rewards differ: crowns against virgins. Also, there will be a time of judgement (2 Cor. 5:10). The question is: why would God judge everyone according to what he/she has done? This implies that God expects everyone to cultivate good moral conduct, since immoral conduct is going to be judged and punished.

\footnotetext{
31 Wilberforce S. Dzisa, “Technology, Innovation and Christian Values: The Catalysts for Progressive Quality Education,” Ghanaweb, September 2, 2017, https://www.ghanaweb.com.

32 Robert Kunzman, Imaginative Engagement with Religious Diversity in the Public School Classrooms, (Religious Education, 2006 ), 516-531.

33 Catharine R. Whittaker, Spencer Salend, and Hala Elhoweris, Religious Diversity in Schools: Addressing the Issues (New York: Departments Diversity Dispatches, 2009), 318 .

34 Assembly Press. Ministry of Justice/Allshore Co., 1992 Constitution of the Republic of Ghana. Fundamental Human Rights and Freedom. Chapter Five 12 (2). (Accra: Assembly Press. Ministry of Justice/Allshore Co., 2005).

35 John Hick, Problems of Religious Pluralism. (The Macmillan Press, 1985), 49

36 Macaulay, "The Future of Taboos in Indigenous Ghanaian Morality," 339.

37 Kwame Gyekye, African cultural values: An introduction (Accra: Sankofa Publishing Company, 1996), 55. Also in An essay on African philosophical thought: The Akan conceptual scheme, (rev. ed.). Philadelphia: Temple University Press.
} 
Absolutely essential, they also pray for the prevalence of peace in the country and love among the citizens. But the questions are: where is the love? Why are the teachings and prayers of these religious groups unable to promote enough morality? Why are social vices, such as armed robbery, bribery, corruption, sexual immorality, kidnapping, and "sakawa" (internet fraud) on the increase? Clifford posited that it is not the faith that must be judged, but the actions following the belief. He points out that acting in a way that is opposite of one's belief seems to condemn the belief. ${ }^{38}$ Some religious leaders have blamed television and social media in general as the impetus for the decline in standards of morality. Nevertheless, since each of these religions has its ethical doctrines, they should mould lives, and live in the fear of God or Allah, and love one another. They should also teach the adherents how to work to fulfil their creative potential. By work, "we affirm that we are truly human. Because if a person does not want to work when he has the energy, he then ceases to be truly human." ${ }^{\prime 39}$ It is God who called human beings to work.

Expectantly, Ghanaians look forward to seeing religious people living religion and not only defending it without checking the way they behave. These religions easily or proudly dismiss, if not condemn, one another as a false religion, instead of being explicit about their teachings in order to influence their hearers. These negative, harmful or unpleasant attitudes breed division; arouse hostility, and intolerance in communities.

According to Macaulay, one cannot become morally good apart from having a genuine religious experience. According to him, love for God is the basic tenet of one to have love for his neighbour (Mk. 12: 30-31; 1John 4:2021). ${ }^{40}$ This he explains to mean that the level of one's love for God is the determinant of the level of one's love for his neighbour. If one does not have love for his neighbour; one does not have love for God. He further explains that, those who are to worship, pray and teach others the knowledge of God ought to be well acquainted with his love and holiness themselves (Is. 6:1-9). Macaulay, then, posits that, Pastors should be able to encounter the love and holiness of God themselves, without which they would be found wanting to teach others about this holy and loving God. Comparatively, if it is true that in Al-Jumu ah 62:1 there is the concept that Allah is a spirit and indeed he is holy, then, Imams are not exempted. Since love and holiness are some of the distinctive attributes of God, discrimination and intolerance have no place in him, and therefore, must be done away with. For God's holy love cannot be demonstrated in hostility. Hence the Lord Jesus said, "Love your enemies and pray for those who persecute you" (Matt. 5:44).

Notwithstanding the breed of discrimination and intolerance, it is believed that the concept of religious pluralism and diversity is also "relevant to human service professions, such as psychology and social work, as well as medicine and nursing, in which trained professionals may interact with clients from diverse faith traditions." ${ }^{41}$ While this could be regarded as an advantage of free association or interaction of one religious member with another, it also has its disadvantage of looking down upon the rival member.

In a society of religious pluralism, the greatest challenge to any faith is not to compete with other faiths, but how to relate with other religious groups. The issue is about a good relationship. Hence, Stephen Evans asked, "Could one religion be true?" Also, "Is it not intolerant of other faiths to claim that their own religion contains the final truth?" 42 According to Hick, each of these great religious traditions, then, proclaim its own unique superiority over others. ${ }^{43}$ This must be the main impetus behind the intolerance.

Many Protestant Christian groups hold that Jesus Christ is the Son of God and that he died on the cross, was buried and rose again for the wrongdoing of those who will accept the gift of salvation. Hence the Bible declares, "For the message of the cross is foolishness to those who are perishing, but to us who are being saved it is the power of God" (1Cor. 1:18). Again, it says, "And if Christ is not risen, then our preaching is empty and your faith is also empty" (1Cor. 15:14). The church preaches this message because the resurrection of Jesus Christ proved that He was who He said He was -the Son of God as predicted in Luke 1:31, 35 .

Also, through him, prayers will be answered, because He himself said, "And whatever you ask in My name, that I will do" (John 14:13). Nevertheless, maximal forms of religious pluralism claim that "all religions are equally true, or that one religion can be true for some and another for others. Some Christians hold this idea to be logically impossible from the Principle of contradiction." ${ }^{44}$ This assertion is justified by the Christians according to what 1 John 5:11-12 says, "...that God has given us life, and this life is in his Son; he who has the Son has life, and he who does not have the Son of God has no life." This means that God takes the initiative and comes to the soul of man with a transcendent moral claim. Hence, Christian moral values must take centre stage to demonstrate a higher moral standard of living. Muslims also ought to do likewise.

\footnotetext{
38 William K. Clifford, “The Ethics of Belief.” Lectures and Essays. London: Macmillan, 1879.

39 Joshua N, Kudadjie. R. K. Aboagye-Mensah. Christian Social Ethics (Accra: Asempa Publishers, 1992), 108-117.

40 Macaulay, "The Future of Taboos in Indigenous Ghanaian Morality," 339.

41 Friberg Nils, The Role of the Chaplain in Spiritual Care. In David O. Moberg, Aging and Spirituality: Spiritual Dimensions of Aging Theory, Research (2001), 177-190.

42 Stephen C. Evans, Philosophy of Religion: Thinking About Faith. (InterVarsity Press. 1985), 180.

43 Hick, Problems of Religious Pluralism, 49.

44 Jason Carlson, Defending Salvation Through Christ Alone. Christian Ministries International. http://www.christianministriesint.org
} 
Finally, the absolutely fascinating aspect of the argument is that the Lord Jesus Christ, the object of the Christian's devotion and the focal point of all Scripture, did not write a single word of the Bible, instead, holy prophets did (2 Pet. 1:20-21). Though this revelation stands in stark contrast to other religious books, Ghanaians wait in eager anticipation to seeing religious people living morally as they pray to God or Allah. Notwithstanding all the arguments, it has also been made abundantly clear that the two religious bodies need to exhibit sincere love which is a sine qua non for having a positive impact on Ghanaian society.

\section{CONCLUSION}

It has been copiously indicated that prayer is a very crucial important means of communication with God or Allah in Christianity and Islam. After careful scrutiny of all the preceding accounts, it is obvious that the two religions share similar views on the subject, however, with regard to some elements of faith and prayer they share divergent views. One of the divergent views held on effective prayer by these religions is, whether one should pray through a mediator or not. The question is whether or not it is possible, that the one God that they claim to worship is the same God worshipped in different ways by different religions.

Interestingly, each of these religions has its ethical and moral doctrines. Their doctrines are to inculcate a sense of morality to mould the lives of their adherents for the better. This is because some scholars maintain that there is a connection between religion and morality, therefore, those who pray must depend on God's Word as a guideline for their behaviours. The fact is that the role religion plays in shaping the lives of the people of Ghana is losing its place. A typical example is the unprecedented armed robbery.

For prayer to be holistic, as indicated earlier, the Christian prayer group named Aglow International which holds its prayer sessions monthly at The Independence Square needs to be encouraged to grow. This will enable participants to demonstrate their God-given abilities to enhance religious growth and unity in Ghana when it is done in love. Since prayer is an important ingredient in an individual's life, nation-building, and access to have fellowship with God individually, it should not be sold as a commodity instead, prayer should be offered freely in order to make it advantageous to those who need it.

It can be said although different religious beliefs can be a source of support and learning for students, they can create divisions, superiority, and many other challenges. Though the purpose of establishing religious educational institutions is known to the proprietors, educators and policymakers need to provide guidelines and strategies for teaching students to understand, accept, and value religious pluralism and diversity in faith in the society particularly in the second-cycle religious educational institutions across the country.

\section{ABOUT AUTHOR}

Ron Macaulay holds a Master of Philosophy (MPhil) degree from the University of Ghana, Legon - Accra. He is a Minister of the Global Evangelical Church, a Lecturer and the Dean of Students at Global Theological Seminary, Ghana.

\section{BIBLIOGRAPHY}

Asamoah-Gyadu, Johnson K. African Charismatic: Current Developments within Independent Indigenous Pentecostalism in Ghana. Leiden: African Christian Press, 2005.

Assembly Press. Ministry of Justice/Allshore Co., 1992 Constitution of the Republic of Ghana. Accra: Assembly Press. Ministry of Justice/Allshore Co., 2005.

Bari, Osman B. A Comprehensive History of Muslim and Religion in Ghana. Dezine Focus Thinking \& Publishing Co., 2009.

Basinger, David. "Religious Diversity in Public Education." in The Oxford Handbook of Religious Diversity, edited by C. Meister. Oxford: Oxford University Press, 2010.

Blackburn, Simon. Oxford Dictionary of Philosophy. New York: Oxford University Press, 2005.

Bloesch, Donald G. The Struggle of Prayer. San Francisco: Harper \& Row Publishers, 1980.

Carlson, Jason. Defending Salvation Through Christ Alone. Christian Ministries International. www.christianministriesint.org

Clifford, William K. “The Ethics of Belief.” Lectures and Essays. London: Macmillan, 1879.

Collste, Ed Goran. Religious and Ethnic Pluralism in Malaysia. Linkoping: University Electronic Press, 2006.

Dickson, John. The Best Kept Secret of Christian Mission. Zondervan, 2010.

Dickson, Roger E. Biblical Research Library: The Work of God in Response to Prayer. South Africa. Cape Town, 2008 . 
Doms, Cynthia B. "The Positive Effects of Prayer and Faith on Mental Health with an Overview of Integrating the Fifth Task of Life" (Master of Arts in Adlerian Counselling and Psychology, June 2011).

Dovlo, Elom. "Healing and Religious Pluralism in Ghana." Draft Paper Presented at Graduate Seminar, University of Stockholm, September, 2006.

Dzisa, Wilberforce S. "Technology, Innovation and Christian Values: The Catalysts for Progressive Quality Education," Ghanaweb, September 2, 2017, https://www.ghanaweb.com

Evans, Stephen C. Philosophy of Religion: Thinking About Faith. Illinois: InterVarsity Press.1985.

Geisler, Norman L. Christian Ethics: Contemporary Issues and Options. Michigan: Baker Academic. Grand Rapids, 2010.

Gyekye, Kwame. African cultural values: An introduction (Accra: Sankofa Publishing Company, 1996), 55.

Hick, John. Problems of Religious Pluralism. The Macmillan Press, 1985.

Huda, "The 5 Muslim Daily Prayer Times and What They Mean.” Feb 08, 2021. Accessed on April 15, 2021. https://www.learnreligions.com/islamic-prayer-timings-2003811

Kudadjie, Joshua N. and Robert K. Aboagye-Mensah. Christian Social Ethics. Accra: Asempa Publishers, 1992.

Kunzman, Robert. Imaginative Engagement with Religious Diversity in the Public School Classrooms. Religious Education, 2006.

Ledcrach John P. Building Peace: Sustainable Reconciliation in Divided Societies (Washington, DC: United States Institute of Peace, 1997), 20.

Macaulay, Ron. "The Future of Taboos in Indigenous Ghanaian Morality" E-journal of Religious and Theological Studies, 6 No. 7 (2020): 334 - 340. https://doi.org/10.38159/erats.2020101

Mbiti, John S. African Religions \& Philosophy. New Hampshire: Heinemann Educational Books Inc. 1989.

Mugambi, Jesse N. K. A Comparative Study of Religions. Nairobi: Nairobi University Press, 1990.

Nils, Friberg. The Role of the Chaplain in Spiritual Care. In David O. Moberg, Aging and Spirituality: Spiritual Dimensions of Aging Theory, Research 2001.

Opoku, Asare Kofi West African Traditional Religion. Accra: FEP International Private Limited, 1978.

Osemeka, Irene N. "The Management of Religious Diversity in West Africa: The Exceptionalism of the Wolof And Yoruba In the Post-Independence Period," Historia Actual Online, No. 33 (2014): 62.

Quinn, Philip. Religious Diversity and Religious Toleration. International Journal for the Philosophy of Religion, 2001.

Self, David The Lion Encyclopedia of World Religions. Oxford: Wilkinson House, Jordan Hill Road, 2008.

Whittaker, Catharine R., Spencer Salend, and Hala Elhoweris, Religious Diversity in Schools: Addressing the Issues. New York: Departments Diversity Dispatches, 2009. 